\title{
Teaching NeuroImages: A case of isolated hemithalamic overgrowth
}

Isabella Tristano, MD, Guido Cedrone, MD, Fabiana Ursitti, MD, Anna Chiarelli, MD, Davide Maria Biancone, MD, and Alberto Spalice, MD

Neurology ${ }^{\circledR}$ 2018;91:e492-e493. doi:10.1212/WNL.0000000000005912
Correspondence

Dr. Saplice

a.spalice@tiscali.it

Figure Imaging and spectroscopy

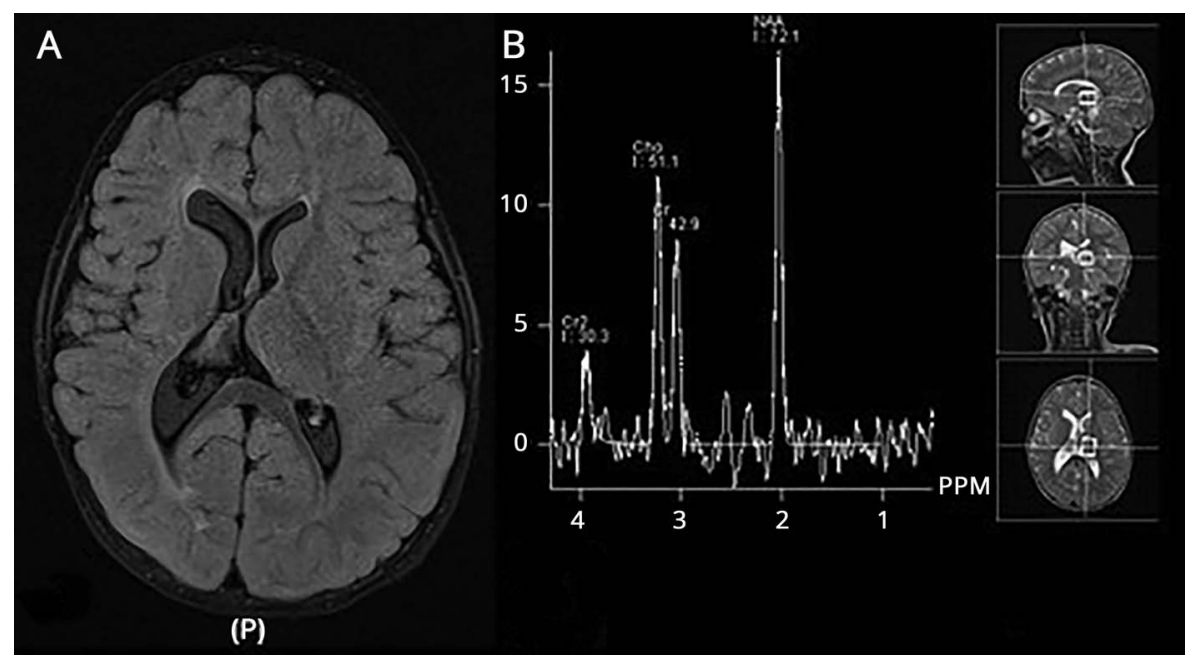

(A) Axial T1 left thalamus overgrowth. (B) Spectroscopy: normal bilateral metabolite peaks.
A 17-month-old boy came to our attention for a left hemiparesis, without any other neurologic disorder. Brain MRI revealed a remarkable hypertrophy of the left thalamus. There were no differences with the right thalamus before and after using contrast, either a hypersignal in fluid-attenuated inversion recovery or restriction at diffusionweighted imaging. In the same way, the spectroscopy showed normal metabolite peaks (choline and $N$-acetylaspartate) ${ }^{1}$ (figure, $\mathrm{A}$ and B). This hemithalamus leaves a mark on the left anterior ventricle with a dilation of the opposite one that could explain the clinical sign.

This is a rare case according to the literature. ${ }^{2}$

\section{Author contributions}

Isabella Tristano: study concept and design, acquisition of data, analysis and interpretation of data, study supervision. Guido Cedrone: acquisition of data, analysis and interpretation of

\section{MORE ONLINE}

$\rightarrow$ Teaching slides

links.lww.com/WNL/A599

From the Child Neurology Division, Department of Pediatrics, "La Sapienza" University, Rome, Italy.

Go to Neurology.org/N for full disclosures. Funding information and disclosures deemed relevant by the authors, if any, are provided at the end of the article. 
data, study supervision. Fabiana Ursitti: analysis and interpretation of data. Anna Chiarelli: analysis and interpretation of data. Davide Maria Biancone: analysis and interpretation of data. Alberto Spalice: study concept and design, critical revision of manuscript for intellectual content.

\section{Study funding}

No targeted funding reported.

\section{Disclosure}

The authors report no disclosures relevant to the manuscript. Go to Neurology.org/N for full disclosures.

\section{References}

1. Yang ZY, Yue Q, Xing HY, et al. A quantitative analysis of (1)H-MR spectroscopy at 3.0 $\mathrm{T}$ of three brain regions from childhood to middle age. Br J Radiol 2015;88;20140693.

2. Della Marca G, Vollono C, Ferraro D, et al. Left thalamomegaly in a patient with partial epilepsy. Clin Neurol Neurosurg 2008;110:298-301. 


\section{Neurology}

\section{Teaching NeuroImages: A case of isolated hemithalamic overgrowth Isabella Tristano, Guido Cedrone, Fabiana Ursitti, et al. Neurology 2018;91;e492-e493 \\ DOI 10.1212/WNL.0000000000005912}

\section{This information is current as of July 30, 2018}

\section{Updated Information \& Services}

References

Subspecialty Collections

Permissions \& Licensing

Reprints including high resolution figures, can be found at: http://n.neurology.org/content/91/5/e492.full

This article cites 2 articles, 0 of which you can access for free at: http://n.neurology.org/content/91/5/e492.full\#ref-list-1

This article, along with others on similar topics, appears in the following collection(s):

All Pediatric

http://n.neurology.org/cgi/collection/all_pediatric

DWI

http://n.neurology.org/cgi/collection/dwi

MRI

http://n.neurology.org/cgi/collection/mri

MRS

http://n.neurology.org/cgi/collection/mrs

Neonatal

http://n.neurology.org/cgi/collection/neonatal

Information about reproducing this article in parts (figures,tables) or in its entirety can be found online at:

http://www.neurology.org/about/about_the_journal\#permissions

Information about ordering reprints can be found online:

http://n.neurology.org/subscribers/advertise

Neurology $®$ is the official journal of the American Academy of Neurology. Published continuously since 1951, it is now a weekly with 48 issues per year. Copyright @ 2018 American Academy of Neurology. All rights reserved. Print ISSN: 0028-3878. Online ISSN: 1526-632X.

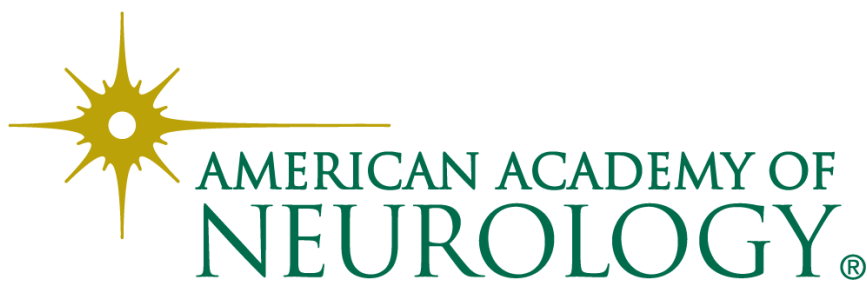

